\title{
A novel activating mutation in the thyrotropin receptor gene in an autonomously functioning thyroid nodule developed by a Japanese patient
}

\author{
Shinji Kosugi ${ }^{1,2}$, Noritaka Hai ${ }^{1}$, Hiroomi Okamoto ${ }^{1}$, Hideo Sugawa ${ }^{1}$ and Toru Mori ${ }^{1}$ \\ ${ }^{1}$ Department of Laboratory Medicine and ${ }^{2}$ Clinical Genetics Unit, Kyoto University School of Medicine, Kyoto 606-8507, Japan
}

(Correspondence should be addressed to S Kosugi, Department of Laboratory Medicine, Kyoto University School of Medicine, 54 Kawahara-cho, Sakyo-ku, Kyoto 606-8507, Japan; Email: kosugi@kuhp.kyoto-u.ac.jp.)

\begin{abstract}
Objective: A number of activating mutations of the thyrotropin receptor (TSHR) have been found in autonomously functioning thyroid nodules (AFTNs) in European patients. We aimed to study TSHR mutation in AFTNs in Japanese patients because no TSHR activating mutation has been found by previous incomplete studies.

Design: A typical AFTN developed in a 69-year-old Japanese woman was studied.

Methods: The entire exon 10 of the TSHR cDNA was sequenced. Functional studies were done by sitedirected mutagenesis and transfection of a mutant construct into COS-7 cells.

Results: We identified a novel heterozygous TSHR gene mutation, Leu 512 $\rightarrow \operatorname{Arg}($ L512R; CTG $\rightarrow$ CCG), from the AFTN. The mutation was not detected in the adjacent normal thyroid tissue. COS-7 cells transfected with L512R mutant TSHR expression vector exhibited a 3.3-fold increase in basal cAMP level compared with that of cells transfected with wild-type TSHR DNA, confirming that the mutation was the direct cause of the AFTN.

TSHR activating mutations involving the third transmembrane helix reported to date are S505R/N and V509A as well as L512R. An in vitro site-directed mutagenesis study encompassing residues 505513 revealed that mutations involving residues other than these three did not show constitutive activation.

Conclusion: This is the first TSHR activating mutation found in a Japanese patient, although true prevalence of TSHR activating mutations in AFTNs developed in Japanese patients remains to be elucidated. In addition, functional studies suggested that amino acid residues in the third transmembrane helix maintaining inactive conformation of the TSHR seem to be located on the same surface of the $\alpha$-helix, possibly making interhelical bonds with another helix.
\end{abstract}

European Journal of Endocrinology 143 471-477

\section{Introduction}

Autonomously functioning thyroid nodules (AFTNs) are a frequent cause $(\sim 30 \%)$ of hyperthyroidism in European populations, but are very rare in Japan ( $\sim 0.3 \%$ of hyperthyroidism) (1). Further, a number of mutations of the thyrotropin receptor (TSHR) have been reported in AFTNs in Europeans (2-8). These mutant TSHRs showed high basal cAMP level without agonist stimulation when transfected into cells without TSHR. They constitutively activated adenylate cyclase and A-kinase and finally led to cellular hyperfunction and proliferation, as well as constitutively activated mutation of $\mathrm{G}_{\mathrm{s} \alpha}, g s p$ (9). The frequency of TSHR activating mutations in AFTNs in European patients differed between reports, but reached up to $80 \%$ when careful full-length sequencing was performed (7). Although it is unknown whether only TSHR or $\mathrm{G}_{\mathrm{s} \alpha}$ activating mutations can give rise to AFTN (10), it is believed that these mutations account for most AFTNs developed in European subjects. Some authors have speculated that these mutations, like ras, gsp, ret and trk mutations (1113), might have been triggered by iodide deficiency due to unknown mechanism(s) (14).

In Japan, Takeshita et al. (15) and Tanaka et al. (16) found only one gsp mutation in a total of 45 AFTNs and toxic multinodular goiters (TMNGs). Murakami et al. (17) examined an AFTN and found another gsp mutation. However, no TSHR activating mutation has been detected to date in Japanese patients, in contrast to 
European populations. Therefore, it has been suggested that there are no TSHR activating mutations in AFTNs in the Japanese population and that the etiology of AFTNs in Japanese subjects may be different from that in Europeans. However, there were serious methodological problems (short analyzed region and insensitive screening methods) especially in the work of Takeshita et al. (15), and the frequency of TSHR mutations would have been markedly underestimated.

We identified a novel, somatic and heterozygous mutation in the TSHR gene in an AFTN developed in a Japanese woman. Here, we report the first TSHR activating mutation to be found in a Japanese patient and discuss the methodological issues in detection of TSHR mutation as well as the functional significance of this novel mutation.

\section{Subject and methods \\ Patient}

A 69-year-old Japanese woman visited the thyroid clinic of Kyoto University Hospital for examination of a thyroid nodule. She had a nodular, elastic-firm, smoothsurfaced, clearly margined, well movable goiter measuring $3.2 \mathrm{~cm} \times 2.5 \mathrm{~cm}$ in the right lobe. Ultrasonography showed a nodule with high echogenecity and high blood flow. The left lobe was atrophic. Laboratory examination revealed that she was mildly thyrotoxic; $\mathrm{T}_{4}, 166 \mu \mathrm{g} / \mathrm{l}$ (normal range, 50-110 $\mu \mathrm{g} / \mathrm{l}$ ); $\mathrm{T}_{3}, 1.87 \mu \mathrm{g} / \mathrm{l}$ (normal, $0.94-1.54 \mu \mathrm{g} / \mathrm{l}$ ); free $\mathrm{T}_{4}, 24.1 \mathrm{ng} / \mathrm{l}$ (normal, $9.8-$ $17.7 \mathrm{ng} / \mathrm{l}$ ); free $\mathrm{T}_{3}, 5.23 \mathrm{ng} / \mathrm{l}$ (normal, $2.8-4.6 \mathrm{ng} / \mathrm{l}$ ); $\mathrm{TSH},<0.03 \mathrm{mU} / \mathrm{l}$ (normal, $0.3-3.9 \mathrm{mU} / \mathrm{l}$ ); thyroglobulin, $137 \mu \mathrm{g} / \mathrm{l}$ (normal, $<45 \mu \mathrm{g} / \mathrm{l}$ ); and TRAb, $5.8 \%$ (normal, -10 to $+10 \%$ ). No abnormal findings were found on chemical or hematological examinations. ${ }^{99 m}$ Tc-pertechnetate thyroidal scintigraphy showed a 'hot nodule' in the right lobe with increased uptake $(4.3 \%$ at $30 \mathrm{~min}$; normal, $0.4-3.0 \%$ for the entire thyroid). The surrounding thyroid was completely suppressed. Under the diagnosis of typical AFTN, right hemithyroidectomy was performed. Histological examination showed clearly encapsulated follicular thyroid adenoma.

\section{Extraction of RNA and genomic DNA, reverse transcription (RT), PCR of exon 10 of TSHR DNA, and direct sequencing}

Informed consent was obtained from the patient for the use of samples for research purposes. Total RNA was extracted by the acid guanidinium-phenol-chloroform method from approximately $100 \mathrm{mg}$ thyroid tissue using RNAzol B (Biotecx Laboratories, Houston, TX, USA) from the tumor and adjacent normal thyroid tissues. Genomic DNA was extracted from the peripheral blood cells as described previously (18). RT was performed on $2 \mu \mathrm{g}$ total RNA (preheated at $70^{\circ} \mathrm{C}$ for
$10 \mathrm{~min}$ ) in $40 \mu \mathrm{l}$ reaction buffer $(25 \mathrm{mM}$ Tris- $\mathrm{HCl}$ (pH 8.3), $50 \mathrm{mM} \mathrm{KCl}, 2 \mathrm{mM}$ dithiothreitol, and $5 \mathrm{mM}$ $\mathrm{MgCl}_{2}$ ) containing $30 \mathrm{pmol}$ oligo(deoxythymidine) $)_{15}$ primer, $20 \mathrm{U}$ avian myeloblastosis virus reverse transcriptase XL (Life Sciences, Petersburg, FL, USA), and $40 \mathrm{U}$ ribonuclease inhibitor (Toyobo, Osaka, Japan) at $42{ }^{\circ} \mathrm{C}$ for $40 \mathrm{~min}$ (19). For PCR amplification of a TSHR DNA fragment of $1445 \mathrm{bp}$ in exon 10, which encodes the entire transmembrane portion and cytoplasmic tail, $4 \mu \mathrm{l}$ RT reaction solution or $10 \mathrm{ng}$ genomic DNA was incorporated in $100 \mu \mathrm{l}$ PCR buffer $(10 \mathrm{mM}$ Tris-HCl (pH 8.5), $50 \mathrm{mM} \mathrm{KCl,} 1.5 \mathrm{mM} \mathrm{MgCl}_{2}$ ) containing $2 \mathrm{U}$ Taq polymerase (Takara, Tokyo, Japan) and $50 \mathrm{pmol}$ each of oligonucleotide primers, $5^{\prime}$-CCTTGAGTCCTTGATGTGTAATG-3' (corresponding to nucleotides +885 to +907) and 5'-CCTTGAGTCCTTGATGTGTAATG-3' $(+2308$ to +2329$)$. Samples were denatured for $5 \mathrm{~min}$ at $94{ }^{\circ} \mathrm{C}$ and then subjected to 35 cycles consisting of $1 \mathrm{~min}$ at $94^{\circ} \mathrm{C}, 1 \mathrm{~min}$ at $58{ }^{\circ} \mathrm{C}$, and $1 \mathrm{~min}$ at $72^{\circ} \mathrm{C}$. The last extension was carried out for $10 \mathrm{~min}$. Purified $\sim 1.4 \mathrm{kbp}$ PCR products were subjected to direct sequencing with the PCR primers and primers derived from exon 10. Sequences from nucleotide +908 to +2307 of human TSHR DNA covering almost the entire exon 10, were determined in both orientations by direct sequencing with a GeneScan DNA sequencer 373A (Perkin-Elmer, Foster City, CA, USA) (18).

\section{Construction of expression vectors, site-directed mutagenesis of the human TSHR DNA, transfection and assays}

WT (wild-type) human TSHR cDNA in the pSG5 vector (Strategene, La Jolla, CA, USA) under control of the SV40 promoter was constructed as reported previously (20). Expression vectors of mutant TSHRs were generated by site-directed mutagenesis using a Gene Editor kit (Promega, Madison, WI, USA) according to the manufacturer's instructions. Mutations were confirmed by DNA sequencing of the final construct. Mutant plasmid DNA was purified by $\mathrm{CsCl}$ gradient ultracentrifugation.

Approximately $10^{7}$ COS-7 cells were transfected with $25 \mu \mathrm{g}$ mutant or WT TSHR DNA or control vector pSG5 DNA by electroporation. When less of the WT TSHR DNA was applied, the total DNA used for transfection was adjusted to $25 \mu \mathrm{g}$ by addition of pSG 5 vector DNA to avoid changes in transfection efficiency and cell viability. Aliquots of the same batch of transfected cells were plated for TSH binding $\left(\sim 5 \times 10^{5}\right.$ cells/well in 6 -well plates) and assays of cAMP and inositol phosphate (IP) production $\left(\sim 10^{5}\right.$ cells/well in 24 -well plates); medium was inositol-free in the latter assay and supplemented with $2.5 \mu \mathrm{Ci} / \mathrm{ml}$ myo- $\left[2-{ }^{3} \mathrm{H}(\mathrm{N})\right]$ inositol (DuPont-NEN, Boston, MA, USA).

All assays were initiated simultaneously $48 \mathrm{~h}$ after transfection and after washing with assay buffer: Hanks' balanced salt solution containing $0.5 \%$ crystalline 
bovine serum albumin (BSA), $20 \mathrm{mM}$ 2-[4-(2-hydroxyethyl)-1-piperazinyl]ethanesulfonic acid (HEPES)$\mathrm{NaOH}$, pH 7.4. $\left[{ }^{125} \mathrm{I}\right] \mathrm{TSH}$ binding was measured after incubation for $2 \mathrm{~h}$ at $22^{\circ} \mathrm{C}$ in $1 \mathrm{ml} \mathrm{NaCl}$-free assay buffer containing $222 \mathrm{mM}$ sucrose, $\sim 100000$ c.p.m. $\left[{ }^{125} \mathrm{I}\right] \mathrm{TSH}(\sim 40 \mu \mathrm{Ci} / \mu \mathrm{g})$ and 0 to $10^{-7} \mathrm{M}$ unlabeled TSH. Total cAMP and IP levels were measured in the same wells after incubation for $1 \mathrm{~h}$ at $37^{\circ} \mathrm{C}$ with $0.2 \mathrm{ml}$ assay buffer containing $10 \mathrm{mM} \mathrm{LiCl}, 0.5 \mathrm{mM} 3$-isobutyl1-methylxanthine, and $10^{-12}$ to $10^{-7} \mathrm{M}$ TSH as noted. Total cAMP was measured by RIA, and IP formation was determined using anion exchange columns. TSH for functional assays and labeling was obtained from the $\mathrm{NIH}$ hormone distribution program (NIDDK-bTSH-I-1, $30 \mathrm{U} / \mathrm{mg}$ ).

All assays were performed at least in triplicate, on at least two separate occasions with different batches of cells, and always included control cells transfected with WT DNA or pSG5 vector alone. LIGAND software was used to calculate the dissociation constant $\left(K_{\mathrm{d}}\right)$ and recpetor density $\left(B_{\max }\right)$ values for TSH binding $(21) . K_{\mathrm{d}}$ data were log-transformed, averaged and reconverted to calculate geometric means. A $K_{\mathrm{d}}$ confidence limit of 95\% was obtained by log-transformation, calculating mean -1.96 S.D. and mean +1.96 S.D., and reconversion (Table 1). Cyclic AMP and IP data are expressed as fold increase over basal in cells transfected with WT TSHR DNA in Table 1, and as fold increase over basal in cells transfected with the pSG5 vector alone in Figs 2 and 3.

To monitor transfection efficiencies, $0.1 \mu \mathrm{g}$ pSVGH was cotransfected with mutant or WT TSHR plasmid DNA, or control vector. Forty-eight hours after transfection, the medium was taken for RIA of human $\mathrm{GH}$ concentration. Data from transfectants in which transfection efficiencies differed more than 10\% from the control were discarded.

To evaluate receptor density estimated by TSH binding experiments, flow cytometric analysis was performed with FLAG-tagged mutant receptors and anti-FLAG antibody. FLAG sequence (DYKDDDDK) was inserted between the 23rd and 24th amino acids of the wild-type TSH receptor construct by site-directed mutagenesis. FLAG-mutant receptors were constructed by ligation. Cell preparation and procedures were essentially the same as previously described $(7,22)$. Cells were incubated with 1:100 diluted anti-FLAG antibody and then with FITC-conjugated anti-mouse IgG. Relative expression level was the ratio between the fluorescence intensity of mutant transfectant and that of wild-type transfectant after subtracting the background of control cells (22).

\section{Results}

\section{Detection of TSHR mutation}

By sequencing the entire exon 10 of the TSHR gene, a novel heterozygous nucleotide substitution of $\mathrm{T}$ to $\mathrm{C}$ was

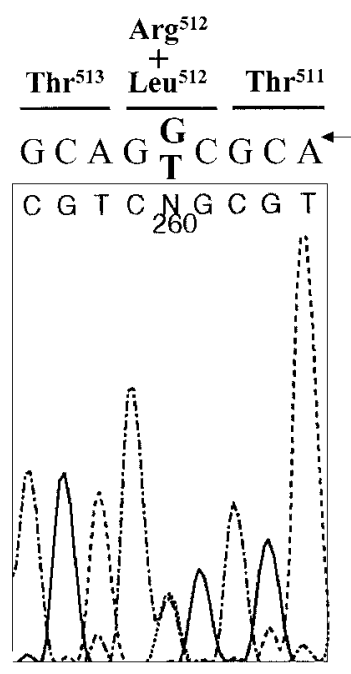

Tumor

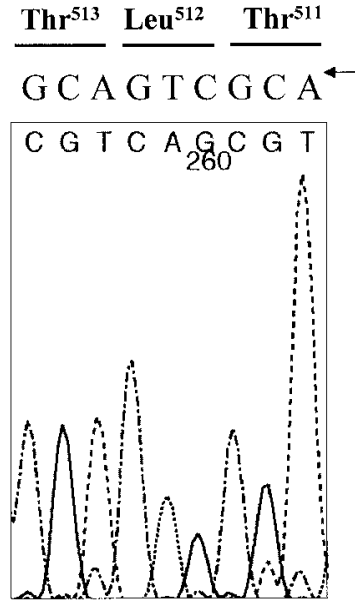

Adjacent thyroid
Figure 1 Sequences around codon 512 of the TSHR gene in the tumor and adjacent thyroid tissue. Antisense sequences are shown. Leu512 (CTG) was heterozygously substituted with Arg (CGG) in the tumor (left panel) but not in adjacent thyroid tissue (right panel). Sequences from peripheral blood cells were the same as the adjacent thyroid.

identified at nucleotide position +1535 , which changed Leu512 to Arg in the third transmembrane helix in an AFTN developed in a Japanese woman (Fig. 1). No other nucleotide changes from the reported sequences except common polymorphisms (23-25) were found in the region from nucleotide +908 to +2307 containing most of exon 10. The L512R mutation was not detected in the adjacent normal thyroid tissue or peripheral blood cells from the patient.

\section{Expression of L512R mutant}

Expression vectors were constructed for the mutant (L512R) and WT TSHR and simultaneously transfected into COS-7 cells. As shown in Fig. $2 \mathrm{~A}$ and Table 1, the L512R transfectant showed a 3.3-fold increase in basal cAMP level compared with that in the WT transfectant, confirming that the mutation was the direct cause of the AFTN in the patient. D633E, which was previously shown to be constitutively activated (20), showed a similar basal cAMP level to the L512R transfectant. However, the L512R transfectant did not respond to TSH-stimulation unlike D633E.

Binding experiments showed that the TSH $K_{\mathrm{d}}$ of L512R was similar to that of WT, but surface receptor density, calculated as $B_{\max }$, was lower than that of WT (Table 1). The transfectant with $5 \mu \mathrm{g}$ WT TSHR and $20 \mu \mathrm{g}$ pSG5 DNA (WT(5)) showed a $B_{\max }$ not higher than that of L512R. The maximal cAMP response to TSH in WT(5) was higher than that in L512R. The receptor densities estimated from the TSH binding study were in good accordance with those determined by flow 
Table 1 Characterization of mutant TSH receptors.

\begin{tabular}{|c|c|c|c|c|}
\hline & WT & L512R & D633E & WT(5) \\
\hline \multicolumn{5}{|l|}{ TSH binding } \\
\hline$K_{\mathrm{d}}(\mathrm{pM})^{\star}$ & $\begin{array}{c}320 \\
(127-804)\end{array}$ & $\begin{array}{c}233 \\
(104-522)\end{array}$ & $\begin{array}{c}144 \\
(46-455)\end{array}$ & $\begin{array}{c}291 \\
(116-731)\end{array}$ \\
\hline$\% B_{\max }(/ \mathrm{WT})^{\star *}$ & 100 & $52.4 \pm 6.0$ & $62.2 \pm 3.5$ & $47.9 \pm 2.9$ \\
\hline$\%$ Re Exp Level (/WT) & 100 & 56 & 65 & 51 \\
\hline \multicolumn{5}{|l|}{ cAMP increase } \\
\hline \%Basal (/WT basal) $)^{\star \star \star \star ~}$ & 100 & $325 \pm 6$ & $333 \pm 15$ & $82 \pm 8$ \\
\hline $\operatorname{Max} \operatorname{Resp}\left(/ \mathrm{WT}\right.$ basal) ${ }^{\star \star \star \star \star}$ & $668 \pm 79$ & $328 \pm 8$ & $689 \pm 29$ & $515 \pm 32$ \\
\hline \multicolumn{5}{|l|}{ IP increase } \\
\hline \%Basal (/WT basal) & 100 & $100 \pm 6$ & $92 \pm 9$ & $99 \pm 9$ \\
\hline Max Resp (/WT basal) ${ }^{\star \star \star \star \star}$ & $798 \pm 32$ & $102 \pm 4$ & $497 \pm 63$ & $384 \pm 38$ \\
\hline
\end{tabular}

${ }^{*}$ Geometric mean. Values in parentheses are $95 \%$ confidence limits. ${ }^{* *} W T$ B $B_{\max }$ averaged $76.5 \pm 16.2 \mathrm{fmol} /$ well. ${ }^{\star \star *}$ Relative expression level estimated by flow cytometry using FLAG constructs. ${ }^{* \star \star \star}$ Basal cAMP level in the wild-type transfectant was $29.5 \pm 2.1 \mathrm{pmol} /$ well. ${ }^{\star \star \star \star \star}$ Maximal response at $10^{-7} \mathrm{MTSH}$. The mutant $B_{\max }, \mathrm{cAMP}$ and IP data (mean \pm S.E.M.) are expressed as percentages of WT TSHR values.

cytometric analysis using FLAG-tagged receptors and anti-FLAG antibody (Table 1).

Constitutive activation of the IP signal was not observed in the L512R transfectant similarly to D633E (Fig. 2B). WT(5) as well as D633E responded well to TSH with a maximal response half that observed in WT. However, no TSH-stimulated IP increase was observed in the L512R transfectant.

\section{Characterization of mutants involving residues 505-513}

In the third transmembrane helix Ser505 and Val509, as well as Leu 512, were found to be mutated in human diseases $(26-28)$. We constructed mutants by substituting one of the residues 505-513 with Ser, Ala or Arg, which were substituted in identified activating mutations involving the third transmembrane helix (Fig. 3). Basal cAMP levels in S505R, V509A and L512R transfectants were higher than that in the WT transfectant, as reported previously $(26,27)$. Other mutants showed lower cAMP levels than WT. As most of the mutants showed lower $B_{\max }$ than WT and basal cAMP level was dependent on $B_{\max }$, constitutive activation can be excluded when the basal cAMP level in the mutant transfectant is lower than that in the WT transfectant with a similar or lower $B_{\max }$. Based on this comparison, no constitutive activation was observed in other mutants.

\section{Discussion}

We identified a novel activating TSHR mutation, L512R, in an AFTN developed in a Japanese patient.
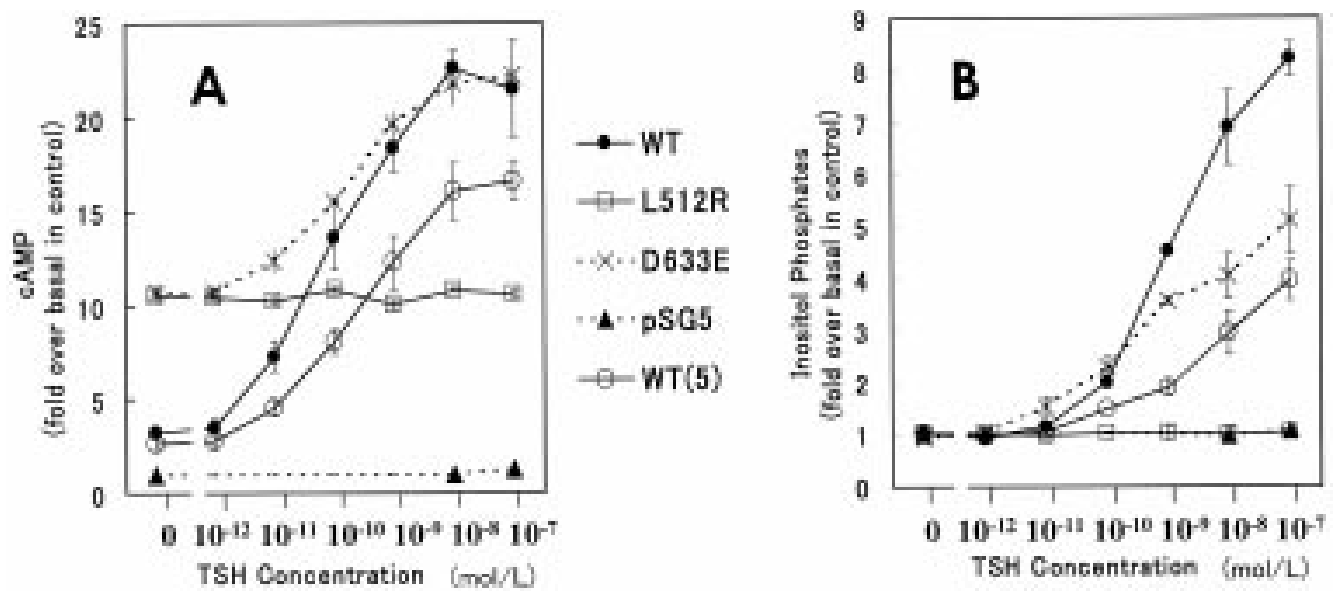

Figure 2 Basal and TSH-stimulated accumulation of cAMP (A) and inositol phosphates (B) in COS-7 cells transfected $48 \mathrm{~h}$ earlier with $25 \mu \mathrm{g}$ each of control vector (pSG5), wild-type human TSHR DNA (WT), or TSHR DNA encoding L512R or D633E (positive control mutant used previously (20)) mutant. WT(5) shows transfectant with $5 \mu \mathrm{g}$ WT TSHR DNA and $20 \mu \mathrm{g}$ pSG5 vector DNA. Data are means \pm S.E.M. of three experiments, and are expressed as fold increase over basal in cells transfected with the pSG5 vector alone. The cAMP level in the control transfectant was $11.2 \pm 0.6 \mathrm{pmol} /$ well. 


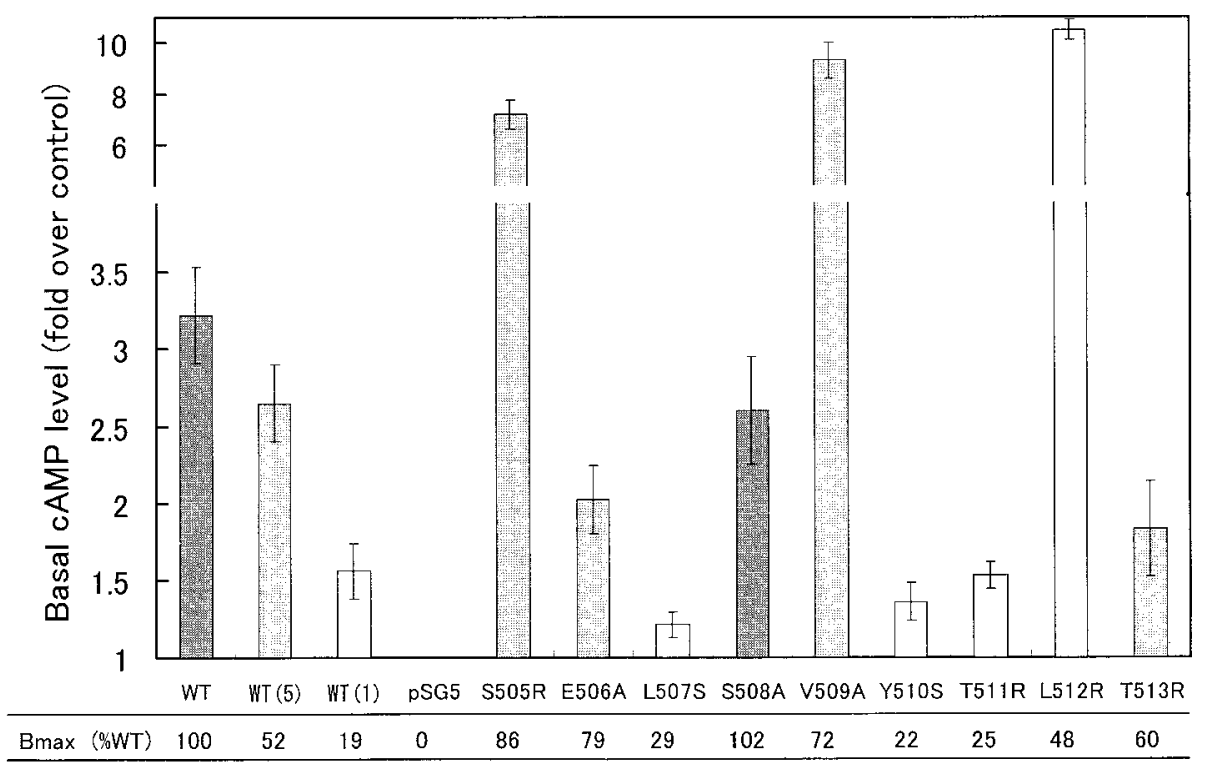

Figure 3 Basal cAMP level of COS-7 cells transfected with TSHR mutant involving one of the amino acid residues 505-513. Values are expressed as fold (mean \pm S.E.M.; $N=6$ ) over basal in control transfectant (pSG5) in an experiment (basal cAMP level in the control transfectant was $10.9 \pm 0.8 \mathrm{pmol} /$ well). Another independent experiment showed similar results. $K_{\mathrm{d}}$ values for each mutant are not shown but ranged from 95 to $397 \mathrm{pmol} / \mathrm{l}$. $B_{\max }$ values estimated from TSH binding are shown and expressed as a percentage of WT transfectant $B_{\max }$. Dark grey columns indicate transfectants with $B_{\max }$ higher than that of $25 \mu \mathrm{g} \mathrm{WT}$ transfectant (WT; $\left.100 \%\right)$. Light grey columns indicate transfectants with $B_{\max }$ higher than that of $5 \mu \mathrm{g}$ WT transfectant (WT(5); $52 \%$ ). White columns indicate transfectants with $B_{\text {max }}$ higher than that of $1 \mu \mathrm{g} \mathrm{WT}$ transfectant (WT(1); 19\%). Cyclic AMP levels in mutant transfectants should be compared with the WT transfectant with the same color column (similar or lower receptor density).

This is the first activating TSHR mutation identified in a Japanese subject including both somatic and germline mutations.

Takeshita et al. (15) examined 38 AFTNs and seven TMNGs in Japanese patients. They found a TSHR gene alteration, $\Delta 619+\mathrm{T} 620 \mathrm{~S}$ (deletion of three adenines) in only one AFTN. This mutant did not show constitutive activation in expression experiments so failing to confirm that this was a disease-causing mutation. They concluded that there was no constitutively activating mutation of the TSHR in AFTNs in the Japanese population. No confirmation study for Japanese population followed this entirely negative and discouraging conclusion. However, caution must be paid in interpreting their results as their methodology seemed to markedly underestimate the frequency of the TSHR mutation. The region in which they were able to analyze mutations was from nucleotide +1829 to +1955 (amino acid residues 610-652), shorter than $1 / 10$ of the exon 10 coding region, and outside the region in which we identified the L512R mutation. They screened for mutations using SSCP (single strand conformation polymorphism), which is known to have low sensitivity (8), using only one protocol with one positive control mutant with eight nucleotide substitutions $(5,29)$. Direct sequencing of this region was performed in only 10 AFTNs, and no mutations were found. However, the presence of mutations in this region could not be excluded using their method because of the possibility of contamination with DNA from cells other than tumor thyrocytes. This was also the case with the report by Paschke et al. (4) who sequenced subcloned TSHR DNA fragments and obtained only one and two clones with a diseasecausing TSHR mutation from 33 and 96 clones examined, respectively. This is why we used RT-PCR for detection of TSHR mutation which should be present only in TSHR-expressing thyrocytes. The intensity of the mutant base signal was the same as that of the wild-type base signal (Fig. 1, left panel).

Our results do not exclude the possibility that the frequency of TSHR mutation in AFTNs in Japanese patients is less than that in European populations. Further extensive studies are necessary to determine the true prevalence of TSHR activating mutations in Japanese AFTNs, although it would be impossible to reexamine the samples previously defined as negative (15).

Leu512 is located in the third transmembrane domain consisting of amino acid residues 495-517. Amino acid sequences of residues 497-517 of the TSHR from all species and corresponding residues of the lutropin/choriogonadotropin receptor from all species are identical, suggesting the structural and/or functional importance of this domain of the TSHR.

In addition to the constitutive activation of the cAMP signal, L512R showed no increase in cAMP or IP by 
TSH stimulation, which was observed with two constitutively activating deletion mutants Del(658661) (7) and $\operatorname{Del}(613-621)$ (8). The very low surface expression ( $1 / 5$ or less) of the mutant receptors may be responsible in $\operatorname{Del}(613-621)$ and $\operatorname{Del}(658-661)(7,8$, $30)$. However, $\mathrm{L} 512 \mathrm{R}$ retained $52 \% B_{\max }$ which was similar to or higher than that of the WT(5) transfectant (Table 1) that showed a good response to TSH (Fig. 2A). It is unlikely that the $\mathrm{L} 512 \mathrm{R}$ mutant receptor is already maximally stimulated because the WT(5) transfectant showed higher cAMP and IP responses to high doses of TSH than L512R. L512R may have a conformation which is inaccessible to agonist or which prevents adoption of the maximally activated structure.

Three activating TSHR mutations involving the third transmembrane helix have been reported to date: S505R/N, V509A and L512R. As these three amino acid residues are spaced 3 or 4 amino acids apart and this portion is very likely to form a simple $\alpha$-helix with a 3.6 amino acid turn, the three residues 505, 509 and 512 seem to face the same direction. This is in contrast to the sixth transmembrane helix where activating mutations are located consecutively (7). To determine whether identification of the three mutated amino acids in the third transmembrane helix was coincidental or was significant, we made a series of point mutations involving one of the residues $505-513$ by substitution with Ser, Ala or Arg. No mutants involving residues other than 505, 509 or 512 showed constitutive activation of the cAMP signal (Fig. 3). Although we examined only one substitution mutant for each residue, it is likely that the three amino acid residues have a structurally specific role(s) in maintaining the inactive conformation of the TSHR. The evidence that such amino acid residues in the third transmembrane helix are located on the same surface of the $\alpha$-helix suggests that one surface of the third transmembrane helix may have interhelical bonds with another helix to maintain the inactive conformation. Results obtained with rhodopsin (31), indicated that the third and seventh transmembrane helices play key roles in activation of the receptor by inducing a conformational change that results in displacement of transmembrane helices 3 and 7 . This is in agreement with constitutive activation of the TSHR by these and several other point mutations in the third and seventh transmembrane domains of the TSHR.

\section{Acknowledgements}

We thank A. Tamada for excellent technical assistance. This work was supported in part by grants-in-aid for Scientific Research from the Japanese Ministry of Education, Science and Culture (Nos 0644128, 06671024, 07671129, 07557353, 08671152, 09671051 and 09257225), Mochida Foundation for Medical and Pharmaceutical Research, Kowa Foundation for Life Science, Shimizu Foundation for Immunology
Research, Kyoto University Foundation, Kurozumi Foundation, Inamori Foundation, Clinical Pathology Research Foundation of Japan, Fujiwara Memorial Foundation, The Mother and Child Health Foundation, Sagawa Foundation for Cancer Research, Kanehara Foundation, Kudo Foundation, The Foundation for Growth Science and SRF for Biomedical Research (all to S.K.)

\section{References}

1 Hamburger JI. The autonomously functioning thyroid nodule: Goetch's disease. Endocrine Reviews 19878 439-447.

2 Parma J, Duprez L, Van Sande J, Cochaux P, Gervy C, Mockel J et al. Somatic mutations in the thyrotropin receptor gene cause hyperfunctioning thyroid adenomas. Nature 1993365 649-651.

3 Porcellini A, Ciullo I, Laviola L, Amabile G, Fenzi G \& Avvedimento VE. Novel mutations of thyrotropin receptor gene in thyroid hyperfunctioning adenomas. Rapid identification by fine needle aspiration biopsy. Journal of Clinical Endocrinology and Metabolism $199479657-661$.

4 Paschke R, Tonacchera M, Van Sande J, Parma J \& Vassart G. Identification and functional characterization of two new somatic mutations causing constitutive activation of the thyrotropin receptor in hyperfunctioning autonomous adenomas of the thyroid. Journal of Clinical Endocrinology and Metabolism 1994 79 1785-1789.

5 Tonacchera M, Cetani F, Parma J, Van Sande J, Vassart G \& Dumont J. Oncogenic mutations in thyroid adenoma: methodological criteria. European Journal of Endocrinology 1996135444 446.

6 Russo D, Arturi F, Suarez HG, Schlumberger M, Du Villard JA, Crocetti-U et al. Thyrotropin receptor gene alterations in thyroid hyperfunctioning adenomas. Journal of Clinical Endocrinology and Metabolism 199681 1548-1551.

7 Parma J, Duprez L, Van Sande J, Hermans J, Rocmans P, Van Vliet $\mathrm{G}$ et al. Diversity and prevalence of somatic mutations in the thyrotropin receptor and Gs $\alpha$ genes as a cause of toxic thyroid adenoma. Journal of Clinical Endocrinology and Metabolism 1997 82 2695-2701.

8 Führer D, Holzapfel H-P, Wonerow P, Scherbaum WA \& Paschke R. Somatic mutations in the throtropin receptor gene and not in the Gsa protein gene in 31 toxic thyroid nodules. Journal of Clinical Endocrinology and Metabolism 199782 3885-3891.

9 Lyons J, Landis CA, Harsh G, Vallar L, Grunewald K, Feichtinger H et al. Two $\mathrm{G}$ protein oncogenes in human endocrine tumors. Science 1990249 655-659.

10 Derwahl M. Editorial: TSH receptor and Gs-alpha gene mutations in the pathogenesis of toxic thyroid adenomas: a note of caution. Journal of Clinical Endocrinology and Metabolism 199681 27832785.

11 Shi YF, Zou MJ, Schmidt H, Juhasz F, Stensky V, Robb D et al. High rates of ras codon 61 mutation in thyroid tumors in an iodidedeficient area. Cancer Research 199151 2690-2693.

12 Goretzki PE, Lyons J, Stacy-Phipps S, Rosenau W, Demeure M, Clark $\mathrm{OH}$ et al. Mutational activation of RAS and GSP oncogenes in differentiated thyroid cancer and their biological implications. World Journal of Surgery 199216 576-582.

13 Wajjwalku W, Nakamura S, Hasegawa Y, Miyazaki K, Satoh Y, Funahashi $\mathrm{H}$ et al. Low frequency of rearrangement of the ret and trk proto-oncogenes in Japanese thyroid papillary carcinomas. Japanese Journal of Cancer Research 199283 671-675.

14 Derwahl M, Manole D, Sobke A \& Broecker M. Pathogenesis of toxic thyroid adenomas and nodules: relevance of activating mutations in the TSH-receptor and Gs $\alpha$ gene, the possible role of iodide deficiency and secondary and TSH-independent molecular mechanisms. Experimental and Clinical Endocrinology and Diabetes 1988106 S6-S9. 
15 Takeshita A, Nagayama Y, Yokoyama N, Ishikawa N, Ito K, Yamashita $\mathrm{T}$ et al. Rarity of oncogenic mutations in the thyrotropin receptor of autonomously functioning thyroid nodules in Japan. Journal of Clinical Endocrinology and Metabolism $1995802607-2611$.

16 Tanaka K, Nagayama Y, Takeshita A, Namba H, Yamashita S, Niwa $\mathrm{M}$ et al. Low incidence of the stimulatory $\mathrm{G}$ protein $\alpha$-subunit mutations in autonomously functioning thyroid adenomas in Japan. Thyroid 19966 195-199.

17 Murakami M, Kamiya Y, Yanagita Y, Koitabashi H, Nagamachi Y, Hosoi Y et al. Primary culture of cells from hyperfunctioning thyroid adenoma with an activating mutation of G $\alpha$ s. Molecular and Cellular Endocrinology 1998138 137-142.

18 Kosugi S, Inoue S, Matsuda A \& Jhiang SM. Novel, missense and loss-of-function mutations in the sodium/iodide symporter gene causing iodide transport defect in three Japanese patients. Journal of Clinical Endocrinology and Metabolism $1998 \quad 83$ 3373-3376.

19 Matsuda A \& Kosugi S. A homozygous missense mutation of sodium/iodide symporter gene causing iodide transport defect. Journal of Clinical Endocrinology and Metabolism 1997823966 3971.

20 Kosugi S, Shenker A \& Mori T. Constitutive activation of cyclic AMP but not phosphatidylinositol signaling caused by four mutations in the 6th transmembrane helix of the human thyrotropin receptor. FEBS Letters 1994356 291-294.

21 Munson PJ \& Rodbard D. Ligand: a versatile computerized approach for characterization of ligand-binding systems. Analytic Biochemistry 1980107 220-239.

22 Duprez L, Parma J, Costagliola S, Hermans J, Van Sande J, Dumont JE et al. Constitutive activation of the TSH receptor by spontaneous mutations affecting the N-terminal extracellular domain. FEBS Letters 1997409 469-474.

23 Nagayama Y, Kaufman KD, Seto P \& Rapoport B. Molecular cloning, sequence and functional expression of the cDNA for the human thyrotropin receptor. Biochemical and Biophysical Research Communications $19891651184-1190$.
24 Frazier AL, Robbins LS, Stork PJ, Sprengel R, Segaloff DL \& Cone RD. Isolation of TSH and LH/CG receptor cDNAs from human thyroid: regulation by tissue specific splicing. Molecular Endocrinology 19904 1264-1276.

25 Misrahi M, Loosfelt H, Atger M. Sar S, Guiochon-Mantel A \& Milgrom E. Cloning, sequencing and expression of human TSH receptor. Biochemical and Biophysical Research Communications $1990166394-403$.

26 Duprez L, Parma J, Van Sande J, Allgeier A, Leclere J, Schvartz C et al. Germline mutations in the thyrotropin receptor gene cause non-autoimmune autosomal dominant hyperthyroidism. Nature Genetics 19947 396-401.

27 Tonacchera M, Van Sande J, Cetani F, Swillens S, Schvartz C, Winiszewski $\mathrm{P}$ et al. Functional characteristics of three new germline mutations of the thyrotropin receptor gene causing autosomal dominant toxic thyroid hyperplasia. Journal of Clinical Endocrinology and Metabolism 199681 547-554.

28 Holzapfel H-P, Wonerow P, von Petrykowski W, Henschen M, Scherbaum WA \& Paschke R. Sporadic congenital hyperthyroidism due to a spontaneous germline mutation in the thyrotropin receptor gene. Journal of Clinical Endocrinology and Metabolism 199782 3879-3884.

29 Chazenbalk GD, Nagayama Y, Russo D, Wadsworth HL \& Rapoport B. Functional analysis of the cytoplasmic domains of the human thyrotropin receptor by site-directed mutagenesis. Journal of Biological Chemistry 1990265 20970-20975.

30 Kosugi S, Mori T \& Shenker A. The role of Asp 578 in maintaining the inactive conformation of the human lutropin/choriogonadotropin receptor. Journal of Biological Chemistry 1996271 31813-31817.

31 Rao VR, Cohen GB \& Oprian DD. Rhodopsin mutations G90D and a molecular mechanism for congenital night blindness. Nature $1994367639-642$.

Received 11 April 2000

Accepted 15 June 2000 